\title{
Tobacco use and its associated factors among older people: a community-based study in Egypt
}

Doaa Abdel-Hady ${ }^{1}$ and Abdel-Hady El-Gilany ${ }^{1}$

${ }^{1}$ Mansoura University, Mansoura, Egypt. (Correspondence to: Doaa Abdel-Hady: doaahady2ooo@gmail.com).

\begin{abstract}
Background: Smoking is a major health risk and tobacco use is common in all age groups in Egypt. In older people, tobacco use is considered the primary preventable cause of disability and death. Few studies have considered tobacco use in older people and its associated factors.

Aims: This study aimed to estimate the prevalence and type of tobacco use among older people in Mansoura, Egypt.

Methods: A cross-sectional descriptive population-based study was carried out in Mansoura District (both urban and rural areas). It included 663 older people aged 60 years or over. Data were collected from interviews at participants' homes using a questionnaire covering family sociodemographic details, tobacco smoking history, nicotine addiction scale, and religious commitment inventory.

Results: The prevalence of active current tobacco smoking among participants was $25.3 \%$, passive smoking was $37.1 \%$, while $6.3 \%$ were ex-smokers. Among active current smokers nicotine dependence was $42.3 \%$, and $23.3 \%$ had failed to quit smoking, while $30.3 \%$ had the intention to quit. Logistic regression analysis revealed that being male, having low levels of education and religiosity, and urban residence were the independent predictors of current smoking.

Conclusion: The prevalence of both active and passive tobacco smoking among older people was considered high compared to high-income countries. The most important factors associated with smoking status were sex, education and religiosity. There is an urgent need for anti-tobacco campaigns and smoking cessation interventions specifically targeting older people.
\end{abstract}

Keywords: smoking, tobacco, nicotine dependence, substance use, Egypt

Citation: Abdel-Hady D; El-Gilany A-H. Tobacco use and its associated factors among older people: a community-based study in Egypt. East Mediterr Health J. 2020;26(1):68-74. https://doi.org/10.26719/2020.26.1.68

Received: 18/05/19; accepted: 12/11/19

Copyright (C) World Health Organization (WHO) 2020. Open Access. Some rights reserved. This work is available under the CC BY-NC-SA 3.0 IGO license (https://creativecommons.org/licenses/by-nc-sa/3.o/igo)

\section{Introduction}

Tobacco use is recognized as one of the biggest public health threats and the primary cause of noncommunicable diseases and premature death in low and middle-income countries (1). It is estimated that $71 \%$ of lung cancers, $42 \%$ of chronic respiratory diseases and nearly $10 \%$ of cardiovascular diseases are due to tobacco smoking (2), while also increasing the risk of communicable diseases such as tuberculosis and lower tract respiratory infections, and decreasing life expectancy $(3,4)$. According to the Egypt Global Adult Tobacco Survey (2009), Egypt is listed as one of the top ten per capita consumers of tobacco, where nearly $20 \%$ of the population use at least one form of tobacco $(5)$, primarily cigarettes $(16 \%)$, waterpipe (3.3\%) and chewing tobacco (2.6\%).

Tobacco use among older people is of particular public health concern, noting the high prevalence in Egypt with regard to elderly citizens (6), who are at a greater risk of side effects associated with long-term tobacco use (7). Smoking tobacco is associated with a higher risk of cognitive impairment and dementia in older people (8) and has also been linked to many sensory disabilities (9), as well as loss of function, mobility and independence (10).
Furthermore, it is associated with age-related diseases in older women such as osteoporosis and breast cancer (11). Lastly, quitting smoking tobacco is more difficult with advancing age due to significant and prolonged nicotine dependence (12).

Although many studies have focused on tobacco use among adolescents and adults, the literature is lacking when examining tobacco use in older and retired people. This study aimed to estimate the prevalence and type of tobacco use among older people in Mansoura, Egypt.

\section{Methods}

This study was carried out in Mansoura District (both urban and rural areas). Mansoura city is the capital of Dakahlia Governorate in Egypt and is considered the base of the Nile Delta, and home to $6.8 \%$ of the total population of the country (13). This cross-sectional descriptive population-based study was conducted between 1 June and 31 August 2017, and targeted the population of older citizens aged 60 years or over.

Sample size was calculated using the Medcalc program (http://www.medcal.org). A pilot study on 50 older persons (not included in the full-scale study) 
revealed that $20 \%$ were current smokers. Using an alpha error of 0.05 , study power of $80 \%$ and $5 \%$ precision, the sample size was re-calculated to be 430 , and then multiplied by 1.5 to compensate for the design effect of the cluster sampling method. Thus, the final sample size was 645 .

The sample was distributed proportionally between rural and urban areas (2:1). Lists of all health centres in urban areas $(n=11)$ and rural areas $(n=38)$ were selected using a simple random sample technique, whereby investigators selected each second and each fourth health centre from urban and rural lists respectively. Older people were selected using a cluster sampling method. The catchment area of each selected health facility was divided into 33 clusters (households), whereby each cluster includes 20 older persons. One or more clusters from each area could be selected depending on the population size and age composition. A total of 692 older people were approached, of which 663 completed the questionnaire (response rate of $95.8 \%$ ).

Data were collected from interviews at participants' homes at times arranged by nurses affiliated with the local health facility. The study questionnaire covered the socio-demographic data of the older person and associated family, tobacco smoking history, nicotine addiction scale, and religious commitment inventory.

The socioeconomic scale of El-Gilany et al. (2012) was used to assess the socio-economic status of the family (14). This validated scale includes education level and occupation of husband and wife, income adequacy and sources, household possessions, and housing conditions. The quartile values of the total score were used to define the four social status levels.

Tobacco smoking history included age of initiating smoking, smoking duration, type of tobacco (e.g. cigarette, waterpipe, cigar, passive smoking at home and/ or work), number of cigarettes (or other) smoked per day, trial to quit, intention to quit, as well as ex-smoking and its duration and reasons. Current smoking is divided into active and passive. Active smoking is defined as the use of any form of tobacco during the past three months on a daily basis. Passive smoking is the exposure to secondhand tobacco at home and/or work, and current exposure was defined as being in the same room with a smoker for at least an hour/ day for 12 consecutive months or more (15).

The smoking index was calculated according to Indryan (2008), which incorporates age of initiating smoking, duration of smoking, type of tobacco use, passive smoking, number of cigarettes (or others) smoked per day, and number of years elapsed since quitting (16). Values less than zero were not considered relevant.

The Arabic Version of the Fagerstrom Test for Nicotine Dependence (FTND), translated and validated by Kassim et al. (2012), was used for measuring nicotine dependence among current tobacco users (17). The test consists of six items with a score ranging from 1 to 10. A score of 5 or more indicates a significant dependence, while a score of 4 or less shows a low to moderate dependence (Heatherton et al.) (18).

The Religious Commitment Inventory (RCI-10) consists of 10 items answered on a 5-point Likert scale; a full-scale score of $\geq 38$ considers a person to be highly religious (19). The English version of RCI-10 was translated to Arabic by two bilingual Egyptian researchers, then back-translated into English by another two translators who were unaware of the English version. The Arabic version was tested during the pilot study and found to be reliable (interclass correlation range 0.72-0.97; Cronbach alpha $=0.73)$.

Data were analysed using SPSS Version 16. Chi square was used to test the significance in bivariate analysis, and crude odds ratios (COR) and their 95\% CI were calculated. Variables significantly associated with smoking in bivariate analysis were entered into a multivariate logistic regression model using forward Wald method. Adjusted OR and their 95\% CI were calculated; $P<0.05$ was considered statistically significant.

\section{Ethical considerations}

The study was approved by the Institutional Review Board of the Faculty of Medicine, Mansoura University, Egypt. Verbal consents were obtained from older persons after explanation of the purpose and nature of the study. Confidentiality of data and privacy were assured.

\section{Results}

The age of study participants ranged from 60 to 85 years with a mean of $67.3 \pm 7.1$ years. Table 1 indicates the number and prevalence of active current smoking (168, 25.3\%) and passive smoking $(246,37.1 \%)$. Among active current smoking, cigarettes smoking is the most prevalent followed by waterpipe smoking. Ex-smokers (not currently passive smokers) totaled 42 (6.3\%) participants. Among those current and ex-smokers (ever smokers), the highest calculated smoking index was 20 to $<40$, and the lowest was $\geq 40$. Among active current smokers, significant nicotine dependence was recorded in 71 (42.3\%) participants, failed trial-to-quit was recorded in 39 (23.3\%) participants, while $51(30.3 \%)$ participants had the intention to quit.

Table 2 illustrates sociodemographic characteristics and their association with tobacco smoking among older people. Being male significantly increases the risk of tobacco smoking [COR $(95 \% \mathrm{CI})=4.8$ (3.3-7.2), $\mathrm{P}<0.001$ ]. In addition, illiteracy, living in urban areas, low level of religiosity and presence of a family member who smokes tobacco are associated with statistically significant increased risk of tobacco smoking among older people [COR $(95 \%$ CI $)=2.2(1.5-3.3), 2.7(1.9-3.9), 3.0(2.0-4.4)$ and 2.1 (1.5-3.0), $\mathrm{P}<0.001$, respectively].

The logistic regression (Table 3) revealed that the most powerful independent predictors were being male and illiterate $[\mathrm{AOR}=6.4(95 \% \mathrm{CI}=4.0-10.2)$ and (3.8-10.9), respectively]. Other independent predictors were low religiosity (3.6 times increase compared to high religiosity) and urban residence (1.9 times increase compared to rural residence). 


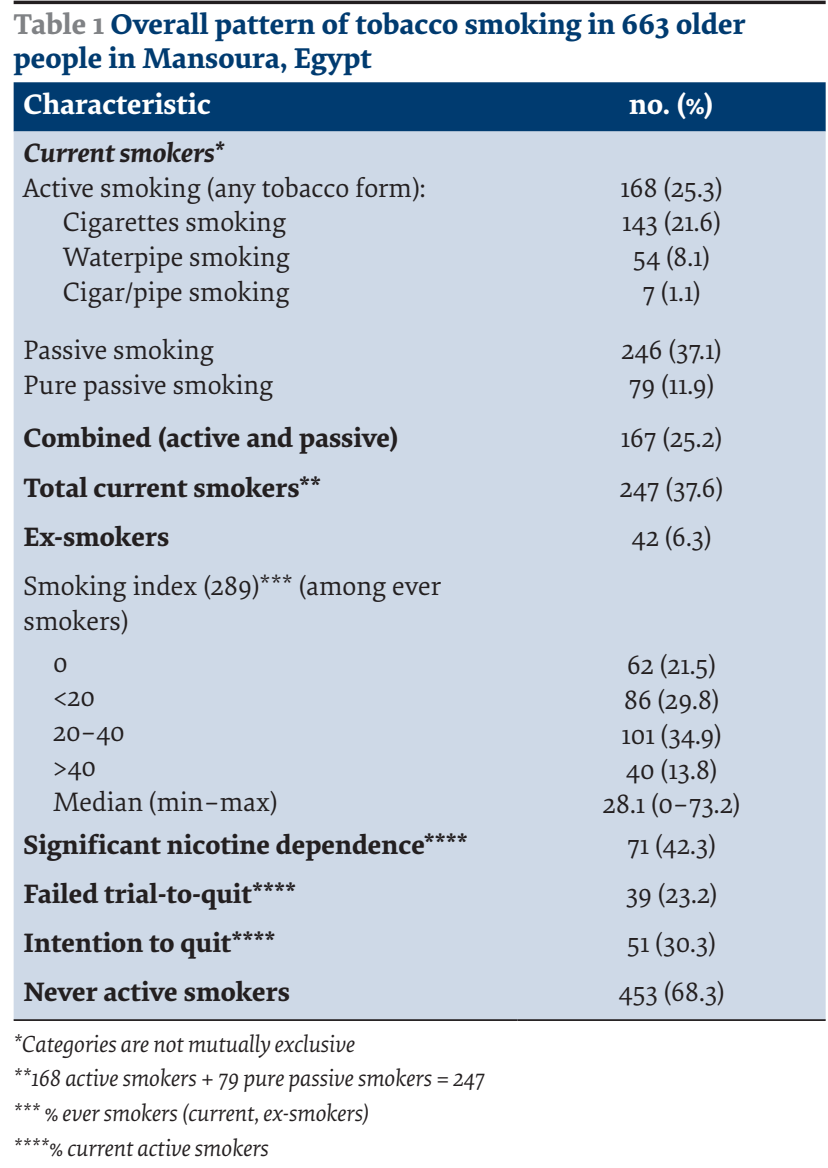

\section{Discussion}

Although tobacco smoking among older people is an important and potentially preventable health issue, few epidemiological studies from the Region have assessed the patterns of smoking exposure among this group. In the present study, the overall prevalence of current smoking among participants aged $\geq 60$ years was $25.3 \%$; this was similar to rates reported by two Brazilian studies where the overall prevalence of smoking among retired individuals were $26 \%$ and $23 \%$ among older people $(20,21)$. However, lower rates were reported from other studies. For example, the overall smoking prevalence in older people ( $\geq 65$ years) in Europe was $11.5 \%$ (22). In the United States of America, It was estimated in 2005 that $9.1 \%$ of adults age 65 years and older were current smokers (6). In Korea, the overall smoking prevalence in older people $(\geq 65$ years old) was $11.9 \%(23)$. In the present study, the prevalence of passive smoking was $37.1 \%$, which is similar to rates reported from other studies; for example, in Italy where $33 \%$ of older people ( $\geq 65$ years old) were exposed to indoor passive smoking (24), while a study from China reported a prevalence of passive smoking in the same age group of $30.5 \%(25)$.

Nicotine is the major chemical component that is responsible for addiction, which is dependent on nicotine amount, the means of delivery and the rate of absorption (26). In this study, $42.3 \%$ of participants were significantly nicotine dependent based on the FTND score; this is much higher than previous study results from other countries. For example, significant nicotine dependence was $25.9 \%$ in older people in Brazil (21), $23 \%$ in a European study (22) and $13.4 \%$ in Italy (27).

Overall, $23.2 \%$ of the current smokers in this study had at least one failed trial-to-quit smoking. This was higher than the rate of failed attempt-to-quit smoking (15.2\%) in one study from India (28), and lower compared to the result of a meta-analysis of tobacco smoking in older people where $36.9 \%$ had made an attempt to quit tobacco use in the past 1 year (11). However, frequent failed quitting reflects the high rate of significant nicotine dependence and /or the lack of proper counseling, support and even medical help needed during the quitting process.

Tobacco smoking is motivated by a complex relationship between environmental, personal, and psychosocial factors and the biological effects of nicotine (29). Still, $30 \%$ of participants in this study had the intention to quit. In other studies, $36 \%$ of older people who smoked tobacco had an intention to quit within the following 6 months (30). However, in 2 other studies approximately half of the study sample demonstrated low motivation to stop smoking $(7,21)$.

The majority of reviewed studies noted that the prevalence of smoking in older people decreases as age increases $(20,30,31)$, falling to only $8 \%$ among those aged $\geq 75$ years (27). In the present study, the prevalence of smoking was almost equal among different age groups, namely $26.5 \%, 23.4 \%$ and $25.5 \%$ in individuals aged $60-$ $<70,70-<80$ and $\geq 80$ years, respectively. This indicates the weak implementation and /or poor effectiveness of smoking cessation programmes for older people.

On stratifying the prevalence of smoking by sex, this study found that it was significantly higher in males than females ( $12.3 \%$ and $40.5 \%$, respectively) and being male is the strongest risk factor for smoking in older people. This concurs with previous reports from other countries $(7,20,22,30)$. A previous study on the prevalence of tobacco use among adults in Egypt detected higher rates of smoking among males than females (32). The observation of the current study may be due to cultural barriers and the social perception of tobacco use by females, which inhibits smoking or at least hinders the disclosure of the actual smoking practice.

As demonstrated in other research (21), marital status is not associated with current tobacco use among older people. A significant inverse relationship between education level and prevalence of current smoking is observed in the current study, which is supported by other research $(25,33)$. Moreover, a lower educational level is a significant independent predictor for current smoking in older people. In addition, a low level of religiosity is indicated to be a significant independent predictor for smoking among older people and could be attributed to the non-observance of numerous religious edicts that declare smoking to be prohibited in Islam (34). 


\begin{tabular}{|c|c|c|c|c|}
\hline & Total & $\begin{array}{l}\text { Smolking } \\
\text { no. }(\%)\end{array}$ & $\boldsymbol{P}$ & $\operatorname{COR}(95 \% \mathrm{CI})$ \\
\hline Overall & 663 & $168(25.3)$ & & $(22.02-28.7)$ \\
\hline \multicolumn{5}{|l|}{ Age (years) } \\
\hline $60-70$ & 355 & $94(26.5)$ & & $1(r)$ \\
\hline $70-80$ & 214 & $50(23.4)$ & 0.4 & $0.8(0.6-1.3)$ \\
\hline$>80$ & 94 & $24(25.5)$ & 0.9 & $0.95(0.6-1.6)$ \\
\hline \multicolumn{5}{|l|}{ Sex } \\
\hline Female & 357 & $44(12.3)$ & $\varepsilon$ & $1(r)$ \\
\hline Male & 306 & $124(40.5)$ & & $4.8(3.3-7.2)$ \\
\hline \multicolumn{5}{|l|}{ Marital status } \\
\hline Divorced/single & 40 & $6(15.0)$ & & $1(\mathrm{r})$ \\
\hline Married & 493 & $136(27.6)$ & 0.1 & $2.2(0.9-5.3)$ \\
\hline Widow & 130 & $26(20.0)$ & 0.5 & $1.4(0.5-3.7)$ \\
\hline \multicolumn{5}{|l|}{ Level of education } \\
\hline Secondary and above & 235 & $47(20.0)$ & & $1(\mathrm{r})$ \\
\hline Less than secondary & 178 & $32(18.0)$ & 0.6 & $0.9(0.5-1.4)$ \\
\hline Illiterate & 250 & $89(35.6)$ & $\varepsilon$ & $2.2(1.5-3.3)$ \\
\hline \multicolumn{5}{|l|}{ Residence } \\
\hline Rural & 443 & $83(18.7)$ & & $1(r)$ \\
\hline Urban & 220 & $85(38.6)$ & $\varepsilon$ & $2.7(1.9-3.9)$ \\
\hline \multicolumn{5}{|l|}{ Living condition } \\
\hline Alone & 32 & $10(31.2)$ & & $1(r)$ \\
\hline With family & 631 & $158(25.0)$ & 0.4 & $0.7(0.3-1.6)$ \\
\hline \multicolumn{5}{|l|}{ Religiosity } \\
\hline High & 289 & $42(14.5)$ & & $1(r)$ \\
\hline Low & 374 & $126(33.7)$ & $E$ & $3.0(2.0-4.4)$ \\
\hline \multicolumn{5}{|l|}{ Currently working } \\
\hline No & 619 & $150(24.2)$ & & $1(r)$ \\
\hline Yes & 44 & $18(40.9)$ & 0.014 & $2.2(1.2-4.1)$ \\
\hline \multicolumn{5}{|l|}{ Income } \\
\hline Adequate & 324 & $76(23.5)$ & & $1(r)$ \\
\hline Not adequate & 188 & $58(30.9)$ & 0.1 & $1.5(0.97-2.2)$ \\
\hline More than adequate & 151 & $34(22.5)$ & 0.5 & $0.9(0.6-1.5)$ \\
\hline \multicolumn{5}{|l|}{ Socioeconomic status } \\
\hline Very low & 150 & $34(22.7)$ & & $1(\mathrm{r})$ \\
\hline Low & 151 & $35(23.2)$ & 0.9 & $1.03(0.6-1.8)$ \\
\hline Middle & 214 & $56(26.2)$ & 0.4 & $1.2(0.7-2.0)$ \\
\hline High & 148 & $43(29.1)$ & 0.2 & $1.4(0.8-2.4)$ \\
\hline \multicolumn{5}{|l|}{ Smoking family member } \\
\hline No & 342 & $64(18.7)$ & & $1(\mathrm{r})$ \\
\hline Yes & 321 & $104(32.4)$ & $\varepsilon$ & $2.1(1.5-3.0)$ \\
\hline
\end{tabular}

COR=crude odds ratio

CI=Confidence interval

\section{Table 3 Multivariate logistic regression analysis of independent predictors of tobacco smoking}

\begin{tabular}{|c|c|c|c|}
\hline & $\beta$ & $\mathbf{P}$ & $\operatorname{AOR}(95 \% \mathrm{CI})$ \\
\hline \multicolumn{4}{|l|}{ Sex } \\
\hline Female & - & & $1(\mathrm{r})$ \\
\hline Male & 1.9 & $E$ & $6.4(4.0-10.2)$ \\
\hline \multicolumn{4}{|l|}{ Religiosity } \\
\hline High & - & & $1(r)$ \\
\hline Low & 1.3 & $\varepsilon$ & $3.6(2.2-6.0)$ \\
\hline \multicolumn{4}{|l|}{ Residence } \\
\hline Rural & - & & $1(\mathrm{r})$ \\
\hline Urban & 0.6 & 0.004 & $1.9(1.2-2.9)$ \\
\hline \multicolumn{4}{|l|}{ Education } \\
\hline Secondary \& above & - & & $1(\mathrm{r})$ \\
\hline Less than secondary & 0.5 & 0.09 & $1.7(0.9-3.0)$ \\
\hline Illiterate & 1.9 & $€$ & $6.4(3.8-10.9)$ \\
\hline Constant & -4.4 & & \\
\hline Model $\chi^{2}$ & $182.0, \leq 0.001$ & & \\
\hline Percent correctly predicted & 81.4 & & \\
\hline
\end{tabular}

AOR $=$ Adjusted odds ratio

$\mathrm{CI}=$ Confidence interval

$\chi^{2}$ Percent correctly predicted 81.4 


\section{Conclusion}

According to this study, active and passive smoking among older people is especially prevalent, and rates of nicotine dependence and failure to quit smoking are high. The most important factors associated with smoking status were gender, levels of education and religiosity.

The observed high rates of smoking among older people compared to high-income countries raises the need for anti-tobacco campaigns and smoking cessation interventions targeting older people, especially males and those with lower levels of education, backed up by the religious rulings on smoking. The high rate of passive smoking is a significant factor that should be studied in depth and lends support to the need for stronger emphasis on anti-smoking laws and smoking cessation strategies in the general population.

\section{Study Limitations}

This is a local study within a single district of Egypt and its results cannot be generalized to the whole country. The religious scale employed was not validated for Islamic culture. Some questions related to the smoking index could allow for the possibility of recall bias.

Funding: None.

Competing interests: None declared.

\section{Consommation de tabac et facteurs associés chez les personnes âgées : étude à base communautaire en Égypte}

\section{Résumé}

Contexte : Le tabagisme constitue un risque majeur pour la santé et la consommation de tabac est répandue dans toutes les groupes d'âge en Égypte. Chez les personnes âgées, le tabagisme est considéré comme la première cause évitable d'incapacité et de décès. Peu d'études ont traité la question de la consommation de tabac chez les personnes âgées et les facteurs qui y sont associés.

Objectifs : La présente étude avait pour objectif d'estimer la prévalence et le type de consommation du tabac chez les personnes âgées à Mansoura (Égypte).

Méthodes: Une étude transversale descriptive en population a été menée dans le district de Mansoura (dans les zones urbaines et rurales). Celle-ci comprenait 663 personnes âgées de 60 ans et plus. Les données ont été collectées à partir d'entretiens réalisés au domicile des participants au moyen d'un questionnaire couvrant les informations sociodémographiques sur la famille, les antécédents de tabagisme, une échelle de dépendance à la nicotine et un inventaire en matière de religiosité.

Résultats : La prévalence de la consommation de tabac au moment de l'étude parmi les participants était de $25,3 \%$ et celle du tabagisme passif était de 37,1\%, tandis que 6,3\% étaient d'anciens fumeurs. Parmi les fumeurs au moment de l'étude, la dépendance à la nicotine était de $42,3 \%$, et 23,3\% n'étaient pas parvenus à arrêter de fumer, tandis que 30,3\% en avaient l'intention. L'analyse de régression logistique a montré que le fait d'être de sexe masculin, d'avoir un faible niveau d'éducation et de religiosité et l'habitat en milieu urbain constituaient les facteurs prédictifs indépendants du tabagisme au moment de l'étude.

Conclusion : La prévalence du tabagisme à la fois actif et passif chez les personnes âgées était considérée comme élevée comparativement aux pays à haut revenu. Les facteurs les plus importants associés au statut tabagique étaient le sexe, l'éducation et la religiosité. Il est urgent de mettre en œuvre des campagnes antitabac et des interventions de sevrage tabagique visant spécifiquement les personnes âgées.

$$
\text { تعاطي التبغ والعوامل المصاحبة له في صفوف كبار السن: دراسة بجتمعية في مصر }
$$

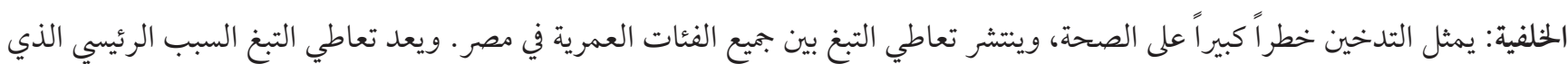

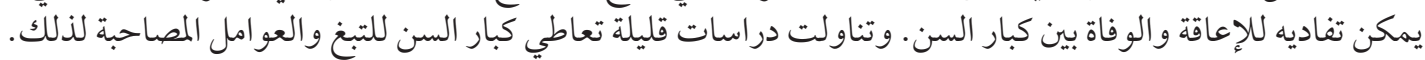

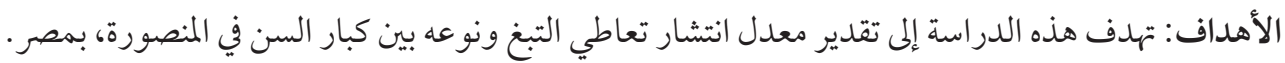

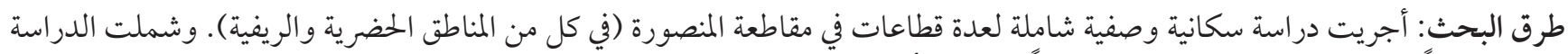

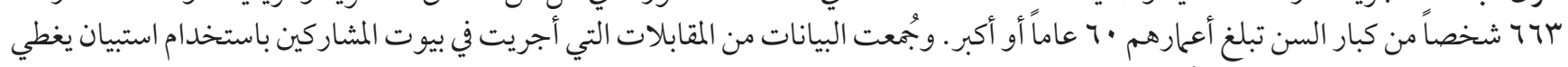

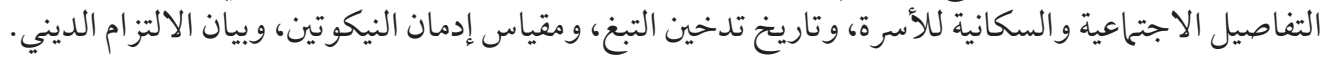

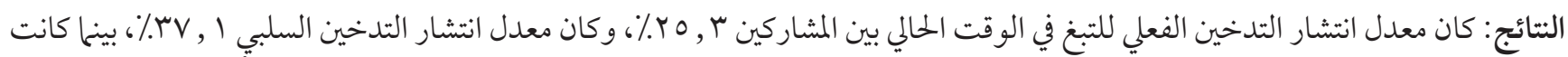

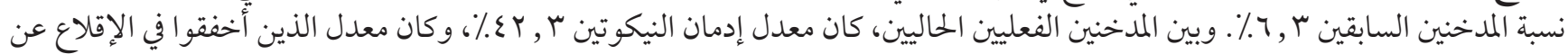




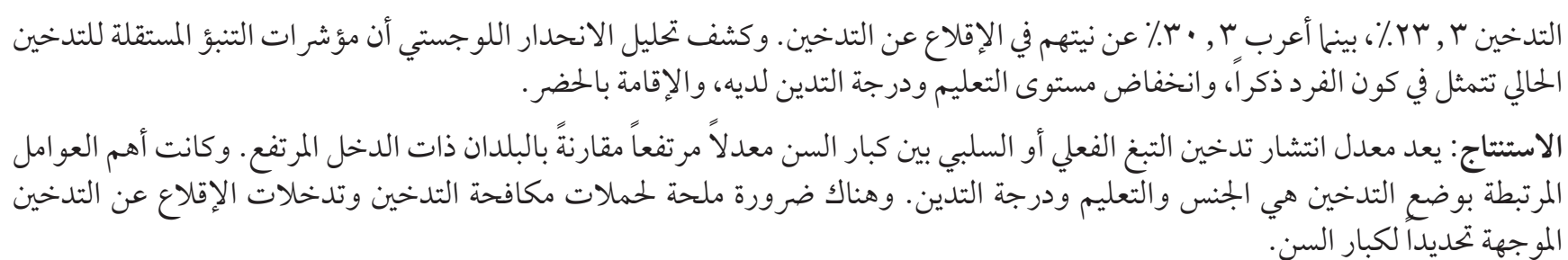

\section{References}

1. World Health Organization. Tobacco: key facts. Geneva: World Health Organization; 2018 (https://www.who.int/en/news-room/ fact-sheets/detail/tobacco, accessed 8 May 2019).

2. Mathers CD, Loncar D. Projections of global mortality and burden of disease from 2002 to 2030. PLoS Med 20.16;3:e442 (https:// doi.org/10.1371/journal.pmed.0030442).

3. Line H, Ezzati M, Murray M. Tobacco smoke, indoor air pollution and tuberculosis: a systematic review and meta-analysis. PLoS Medicine 2007;4:e20 (https://doi.org/10.1371/journal.pmed.0040020).

4. Doll R, Peto R, Boreham J, Sutherland I. Mortality in relation to smoking: 50 years' observations on male British doctors. BMJ 2004;328:1519

5. World Health Organization Regional Office for the Eastern Mediterranean (WHO/EMRO). Egypt global adult tobacco survey (2009): "Tobacco use in Egypt" Cairo: WHO/EMRO; 2009 (http://www.emro.who.int/images/stories/tfi/documents/KF_GATS_ EGY_TU_2009, accessed 8 November 2018).

6. Doolan DM, Froelicher ES. Efficacy of smoking cessation intervention among special populations: Review of the literature from 2000 to 2005. Nurs Res 2006;55(4 suppl 1):S29-S37

7. Marinho V, Laks J, Coutinho ESF, Blay SL. Tobacco use among the elderly: a systematic review and meta-analysis. Cad Saúde Pública, Rio de Janeiro 2010; 26:2213-33 (http://dx.doi.org/10.1590/S0102-311X2010001200002 accessed 8 May 2019)

8. Gons RAR, Van Norden AGW, De Laat, KF, van Oudheusden LJB, van Uden IWM, Zwierset MP, et al. Cigarette smoking is associated with reduced microstructural integrity of cerebral white matter. Brain 2011; 134: 2116-24 (https://doi.org/10.1093/brain/ awr145, accessed 8 November 2018).

9. Nicita-Mauro V, Balbo C L, Mento A, Nicita-Mauro C, Maltese G, Basile G. Smoking, aging and the centenarians. Exp Gerontol. 2008;43:95-101. (https://doi.org/10.1016/j.exger.2007.06.011, accessed 16 November 2018).

10. Schmitt EM, Tsoh JY, Dowling GA, Hall SM. Older adults' and case managers' perceptions of smoking and smoking cessation. J Aging Health 2005;17(6):717-33 (https://doi.org/10.1177/0898264305280995, accessed 6 May 2019).

11. Rapuri PB, Gallagher JC, Smith LM. Smoking is a risk factor for decreased physical performance in elderly women. J Gerontol. 2007;62A(1):93-100 (https://doi.org/10.1093/gerona/62.1.93, accessed 10 March 2019).

12. Abdullah AS, Lam TH, Chan SK, Leung GM, Chi I, Ho WW, et al. Effectiveness of a mobile smoking cessation service in reaching elderly smokers and predictors of quitting. BMC Geriatr 2008;8:25 (https://doi.org/10.1186/1471-2318-8-25, accessed 10 November 2018).

13. State information service (SIS). Dakahlia governorate. Cairo: SIS; 2016 (http://www.us.sis.gov.eg/Story/68563; accessed 9 September 2019).

14. El-Gilany A, El-Wehady A, El-Wasify M. Updating and validation of the socioeconomic status scale for health research in Egypt. East Mediterr Health J 2012; 8(9):962-8 (https://doi.org/10.26719/2012.18.9.962, accessed 7 December 2018).

15. Coogan P, Castro-Webb N, Yu J, O'Connor G, Palmer J, Rosenberg L. Active and passive smoking and the incidence of asthma in the black women's health study. Am J Respir Crit Care Med. 2015;191(2):168-176

16. Indryan A. Medical biostatistics. Boca Raton, FL: Chapman \& Hall/CRC Biostatistics Series; 2008:228-230

17. Kassim S, Salam M, Croucher R. Validity and reliability of the Fagerstrom Test for Cigarette Dependence in a sample of Arabic speaking UK-resident Yemeni khat Chewers. Asian Pac. J. Cancer Prev 2012;13:1285-88 (https://doi.org/10.7314/APJCP.2012.13.4.1285, accessed 10 November 2018).

18. Heatherton TF, Kozlowski LT, Frecker RC, Fagerström K-O. The Fagerstrom Test for Nicotine Dependence: a revision of the Fagerstrom Tolerance Questionnaire. Br J Addict 1991;86:1119-27 (https://doi.org/10.1111/j.1360-0443.1991.tbo1879.x, accessed 12 November 2018).

19. Worthington EL, Wade NG, Hight TL, Ripley JS, McCullough M, Berry JW, et al. The Religious Commitment Inventory-10: development, refinement and validation of a brief scale for research and counseling. J Couns Psychol 2003;50(1):84-96 (https://doi. org/10.1037/0022-0167.50.1.84, accessed 15 November 2018).

20. Bratzler DW, Oehlert WH, Austelle A. Smoking in the elderly - it's never too late to quit. J Okla State Med Assoc 2002; 95(3):185-91

21. Carvalho AA, Gomes L, Loureiro AML. Smoking in elderly patients admitted to long-term care facilities. J Bras Pneumol 2012;36(3):339-46 (https://www.researchgate.net/publication/45168059, accessed 12 October 2018). 
22. Lugo A, La Vecchia C, Boccia S, Murisic B, Gallus S. Patterns of smoking prevalence among the elderly in Europe. Int J Environ Res Public Health 2013;10:4418-31 (https://doi.org/10.3390/ijerph10094418, accessed 10 May 2019).

23. Kim SK, Park JH, Lee JJ, SB Lee, Kim TH, Han JW, et al. Smoking in elderly Koreans: prevalence and factors associated with smoking cessation. Arch Gerontol Geriatr 2013;56:214-9 (https://doi.org/10. 1016/j.archger.2012.08.018, accessed 10 May 2019).

24. Simoni M, Jaakkola MS, Carrozzi L, Baldacci S, Di Pede F, Viegi G. Indoor air pollution and respiratory health in the elderly. Eur Respir J. 2003;Suppl 40:15s-20s (https://doi.org/10.1183/09031936.03.00403603, accessed 8 March 2019).

25. Yang S, He Y, Liu M, Wang Y. Changes in and patterns of smoking exposure in an elderly urban population in Beijing: $2001-2010$. PLoS ONE 2015;10(3):e0118500 (https://doi.org/10.1371/journal.pone.0118500, accessed 17 November 2018).

26. Balfour DJ. The neurobiology of tobacco dependence: a preclinical perspective on the role of the dopamine projections to the nucleus accumbens. Nicotine Tob. Res. 2004;6(6):899-912 (https://doi.org/10.1080/14622200412331324965, accessed 5 May 2019).

27. Gallus S, Pacifici R, Colombo P, Vecchia C, Garattini S, Apoloneet G, et al. Tobacco dependence in the general population in Italy. Ann. Oncol 2005;16:703-6 (https://doi.org/10.1093/annonc/mdi153, accessed 18 April 2019).

28. Rupali AP, Gautam M K. Study of knowledge, attitude and practices towards tobacco use in geriatric population. Int J Med Sci Public Health 2014;3(7):859-62 (https://doi.org/10.5455/ijmsph.2014.170420144), accessed 12 November 2018

29. De Araújo AJ, Menezes AM, Silva Dórea AJ, Torres BS, Viegas CA, Silva CA, et al. Guidelines for smoking cessation. J Bras Pneumol. 2004;30(2):S1-S76

30. Peixoto SV, Firmo JO, Lima-Costa MF. Health conditions and smoking among older adults in two communities in Brazil (The Bambuí and Belo Horizonte Health Surveys). Cad Saude Publica 2006;22(9):1925-34 (http://dx.doi.org/10.1590/So102311X2006000900024, accessed 11 November 2018).

31. Linardakis M, Smpokos E, Papadaki A, Komninos ID, Tzanakis N, Philalithis A. Prevalence of multiple behavioral risk factors for chronic diseases in adults aged 50+, from eleven European countries - the SHARE study (2004). Prev. Med. 2013;57:168-172 (http://dx.doi.org/10.1016/j.ypmed.2013.05.008, accessed 9 March 2019).

32. Fouad H, El-Awa F, Abou El Naga R, Emam A, Labib S, Palipudiet K, et al. Prevalence of tobacco use among adults in Egypt, 2009. Glob Health Promot 2013;23(S2):38-47 (https://doi.org/10.1177/1757975913499801, accessed 14 April 2019).

33. Gallus S, Lugo A, La Vecchia C, Boffetta P, Chaloupka F, Colombo P, et al. Pricing policies and control of tobacco in Europe (PPACTE) project: cross-national comparison of smoking prevalence in 18 European countries. Eur J Cancer Prev. 2014; 23(3):17785 (https://doi.org/10.1097/CEJ.0000000000000009, accessed 30 September 2019).

34. World Health Organization regional Office for the Eastern Mediterranean (WHO/EMRO). Islamic ruling on smoking. Cairo: WHO/EMRO; 2013. 